\title{
Non-invasive moisture content measurement system based on the ESP8266 microcontroller
}

\author{
Agustami Sitorus ${ }^{1}$, Novrinaldi ${ }^{2}$, Ramayanty Bulan $^{3}$ \\ ${ }^{1,2}$ Research Center for Appropriate Technology, Indonesian Institute of Sciences, Indonesia \\ ${ }^{3}$ Department of Agricultural Engineering, Syiah Kuala University, Indonesia
}

\section{Article Info \\ Article history: \\ Received Nov 12019 \\ Revised Jan 21, 2020 \\ Accepted Feb 20, 2020}

\section{Keywords:}

Apparatus

Microcontroller

Moisture content

Non-delay

Sensors

\begin{abstract}
Moisture content in the process of drying is often unknown when carrying out the drying process, especially the fluidized dryer. A lot of experimental designs are needed when observing the drying phenomenon more deeply. It is because to stop and repeat the drying process from the beginning again when the sample is taken to test its moisture content needed more experiments. Therefore, this paper presents the development of a non-intrusive moisture measurement system prepared for fluidization type dryers. The method used in to conduct this research consists of (i) structural design analysis and (ii) functional (mechanical and electrical systems) and (iii) simple testing of the water content measurement system of constructed material. Test parameters observed include errors in measuring and fluctuating sensor signals against vibration applied to the weighing system. The results showed that non-intrusive moisture content measurement system for fluidized dryers based on the ESP8266 microcontroller had been successfully developed and worked normally. The measurement system has been calibrated with a coefficient of determination $\left(\mathrm{R}^{2}\right)$ close to one. Measurement error resulting from the effect of vibration on this system shows a very satisfactory value of $6.89 \%$.
\end{abstract}

This is an open access article under the CC BY-SA license.

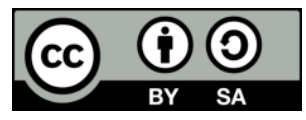

\section{Corresponding Author:}

Agustami Sitorus,

Research Center for Appropriate Technology (P2TTG),

Indonesian Institute of Sciences (LIPI),

Jl. Ks. Tubun No.5, West Java, 41213, Indonesia.

Email: aguslipi122@gmail.com

\section{INTRODUCTION}

Drying is one of the oldest methods and requires a lot of money and time-consuming for the preservation of food or biologically active products [1-5] such as grains for decreasing the water content. Decreasing the water content of a dried product is very important to know from a dryer. It is to show the extent to which the product has reduced its water content. The performance of a dryer can be demonstrated by the drying rate and drying time parameters that start from measuring the moisture content of the dried product [6-9]. The suitability of the reduction in water content with the product's ability to release water becomes the focus of the investigation in addition to the energy requirements in the drying process. It is because agricultural products that are processed with dryers are easily damaged if not handled properly [10-12] and requires a lot of energy [13-19].

Various types of dryers and methods for measuring the moisture content of dried products continue to be developed. At present, the fluidization desiccant tends to be more widely studied and applied for drying, especially for agricultural materials. It according to several research results has advantages including being 
efficient in delivering heat, giving uniform thermal to the product, significant drying rate, shorter drying time and relatively fast mass transfer rate [6, 20-24].

Methods for measuring the moisture content of a product during the drying process are still being developed. The conventional method, which is still being used in estimating the moisture content when drying is by taking samples of the dried product. It was conducted by Li et al. [8], which uses an electric drying oven (DHG-9040A; Hangzhou Lantain Instrument Co. Ltd., China) for grain. The grain used in this study was $500 \mathrm{~g}$ with moisture content $25 \%$ wet basis. $15 \mathrm{~g}$ of rice was taken as a sample for eleven observations. Other studies such as those conducted by Chuwattanakul and Eiamsa-ard [23] in measuring the moisture content of a product from a swirling fluidized bed dryer (SFBD) dryer for pepper seeds. The SFBD works at $70^{\circ} \mathrm{C}$ with the mass of pepper fed at $200 \mathrm{~g}$ with a moisture content of $73 \%$ (w.b.). Pepper seed samples are taken every 10 minutes for one hour to determine the water content. It shows that the drying load on the tool will vary at each time interval caused by taking the material as a sample for the moisture content test.

On the one hand, the method that determines the time to measure water content in the middle of the drying process will require many experiments because it has to do the drying process repeatedly. It is intended that the number of samples to be dried has the same mass load in each drying process, as did Yogendrasasidhar and Setty [22]. On the other hand, several studies do not focus on the effect of reducing the mass of dried products because they are taken for samples [8, 23]. Another method is to use a relatively expensive water content sensor, as conducted by Firouzi et al. [7].

However, some research using the weighing balance to find out the mass of the dried product by measuring the entire mass of the product along with the dryer as done by Chokphoemphun and Chokphoemphun [6]. Another method is to develop sensor devices such as those carried out by Zhang et al. [20] and Zhang et al. [21] for determining non-intrusive water content in a fluidizing type dryer. This device uses an electrostatic sensor array that is placed on the wall in the drying chamber. However, the influence of the speed factor of the fluidization of the material and the magnitude of the root-mean-square of the sensor signal fluctuations is a challenge in this method. It is why the error of the devices found in this study ranged from $8 \%-15 \%$.

To know the phenomenon during drying (not only the final quality of the product), but it is also important to develop a non-intrusive method of measuring water content for other fluidizing dryers, which are more effective. Loadcell sensors equipped with microcontrollers have the advantage of being relatively inexpensive, more straightforward construction, easy to find electrical components, sensitivity, and response that can be adjusted. Therefore, this paper presents the development of a system for measuring water content in laboratory-scale fluidized dryers. The relationship between water content and characteristics of the loadcell sensor signal is investigated and modeled. Estimation of material content estimation data is recorded and directly transferred via the internet to the personal computer.

\section{MATERIAL AND RESEARCH METHOD}

In this study, a system designed to estimate water content in a dried product, especially for a fluidizing type dryer on a laboratory scale. This methodology is separated into four stages: (i) design (ii) construction, (iii) functional testing and calibration, and (iv) testing of the system without being integrated with a dryer. Parts of a laboratory-scale non-intrusive water level measurement system are presented in Figure 1. The weighing basket is designed at the bottom in a conical shape with an angle of $55^{\circ}$, a flat diameter of $50 \mathrm{~mm}$, and a height of $300 \mathrm{~mm}$. The form of the basket adjusts to the swirling fluidized bed dryer. The height of the tool frame is $1000 \mathrm{~mm}$ with a length and width of legs of $500 \mathrm{~mm}, 500 \mathrm{~mm}$, respectively. A mass measuring sensor with $5000 \mathrm{~g}$ capacity is placed at the top of the tool frame. A control box as an electrical device container is placed on one side of the tool frame.

The schematic diagram of the electrical devices contained in the control box is presented in Figure 2. A microcontroller is prepared to be able to acquire and transmit sample mass measurement data. An indicator display on the control box is also embedded so that the operator can monitor the progress of the drying process. A feature for setting initial mass and water content is also prepared in this water content measurement system. The working procedure for measuring non-intrusive water content is presented in Figure 3. The sample used in this test was soybean obtained from a local farm shop. 


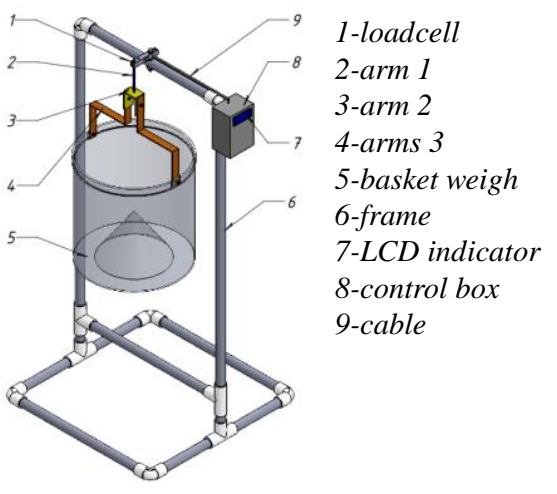

Figure 1. Schematic design of a system for measuring non-intrusive water content

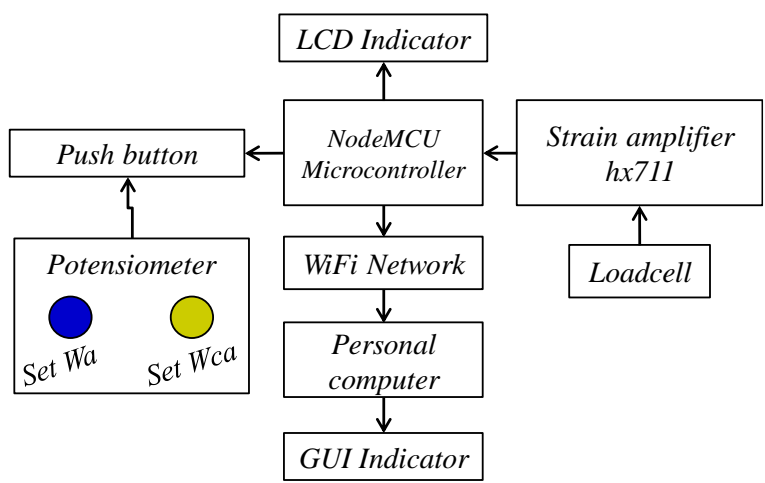

Figure 2. Schematic diagram of an electronic device measuring non-intrusive water content

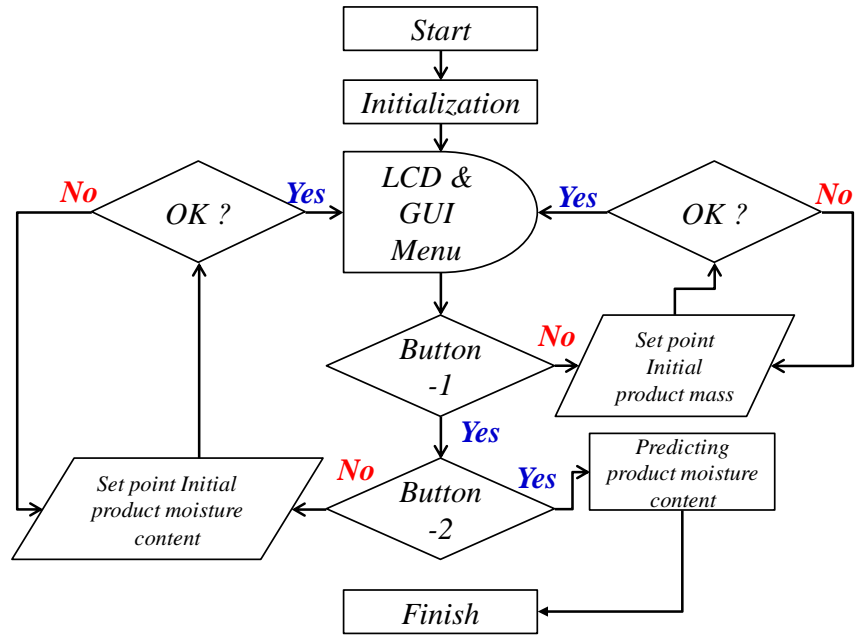

Figure 3. Workflow chart of non-intrusive water content measurement system

\subsection{Data collection and preparation}

The moisture content measurement system is tested by giving a load in the form of soybean samples with mass variations from $100 \mathrm{~g}$ to $2000 \mathrm{~g}$. Soybean mass was weighed using a digital scale $(0.00 \mathrm{~g})$, and the initial water content of soybean was put at $10 \%$. The sample mass recorded by the sensor and waits until \pm 5 minutes. The moisture content of the sample material against time is calculated using (1-3). The equation becomes one of the algorithms embedded in the microcontroller.

$$
\begin{aligned}
& M_{s}=\frac{M_{w a}\left(1-W_{c a}\right)}{W_{c a}} \\
& M_{w a}=W_{c a} \cdot W_{a} \\
& W_{c(i)}=\frac{\left(W_{(i)}-M_{s}\right)}{W_{(i)}}
\end{aligned}
$$

where, $M_{s}$-mass solids $(g), M_{w a}$-initial mass of water $(g), W_{c a}$-initial water content $(\%, w . b$. $), W_{a^{-}}$initial mass samples $(g), W_{c(i)}$-water content of material to $i(\%, w . b),. W_{(i)}$-mass of material to- $i(g)$.

The effect of the shaking factor on the stability of the sensor reading is investigated by varying the amplitude of the weighing baskets of $20 \mathrm{~mm}, 40 \mathrm{~mm}, 60 \mathrm{~mm}, 80 \mathrm{~mm}$, and $1000 \mathrm{~mm}$, respectively as shown in Figure 4. During the shock, the mass of the sample will always be measured until the basket is stationary and added 60 seconds. 


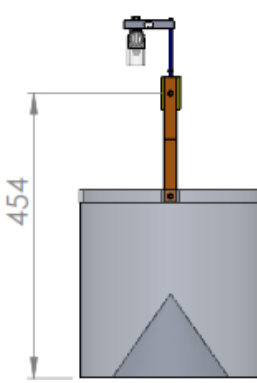

Amp $0 \mathrm{~mm}$

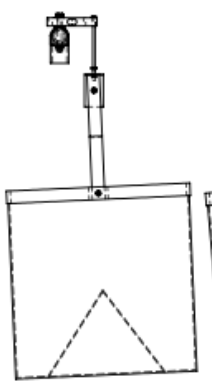

Amp $20 \mathrm{~mm}$

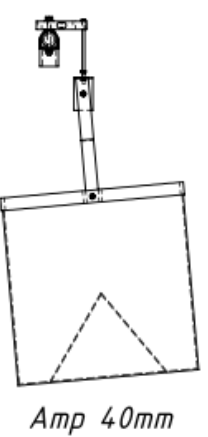

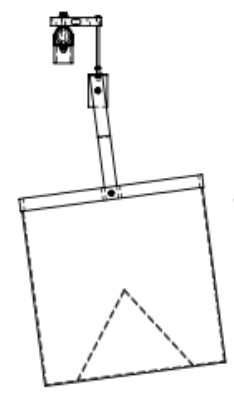

Amp $60 \mathrm{~mm}$

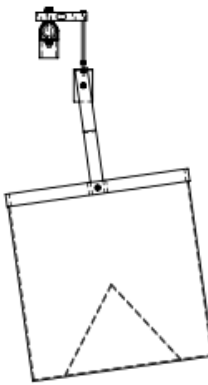

Amp $80 \mathrm{~mm}$

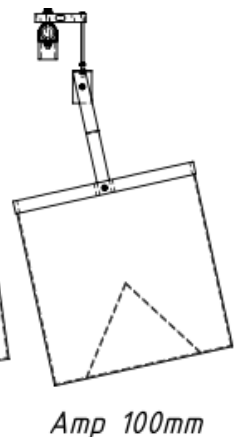

Figure 4. The amplitude applied to the device

\subsection{Estimation of product water content}

Estimation of changes in product water content is done by developing (1) until (3) into a programming algorithm. Measurement data from sensors that refer to the weight of the material in the weigh basket become an independent factor in this system. The dependent factor is the input data in the form of mass and initial water content of the material to be entered into the weigh basket by the operator. The amount of mass and initial moisture content of the product are monitored on the monitor screen that is prepared in the control box.

\section{RESULTS AND ANALYSIS}

\subsection{Design of non-intrusive moisture content measurement system}

\subsubsection{Mechanical components}

The mechanical hardware components of the non-intrusive water level measuring system are presented in Figure 5. The tool frame is made of a $12.7 \mathrm{~mm}$ diameter pipe. Weigh basket with aluminum material has a thickness and the number of holes of $1 \mathrm{~mm}, 10 \mathrm{mesh}$, respectively. The swinging arm is made of a $3 \mathrm{~mm}$ diameter wire. The weigh basket becomes a container for the sample to be placed when drying fluidization is carried out.

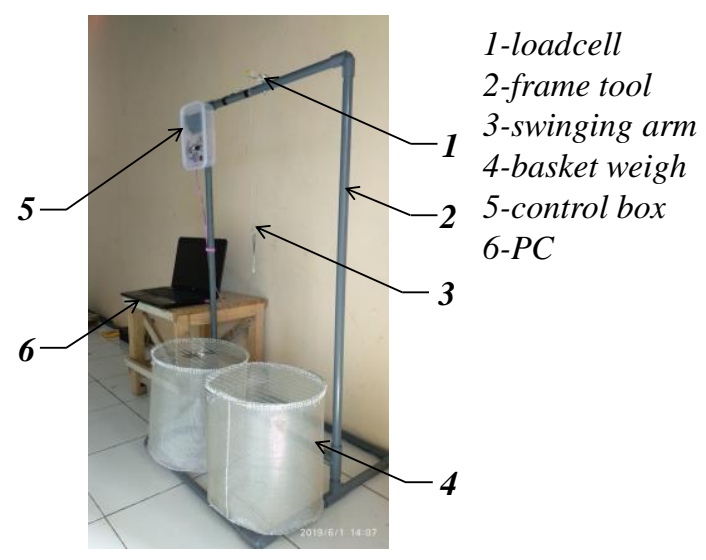

Figure 5. Mechanical components of the system

\subsubsection{Electrical components}

This component uses the ESP8266 data processor in the form of a Nodemcu microcontroller as shown Figure 6. This type of microcontroller was chosen because it has been supported for serial communication online so that the data measured by the sensor can be immediately transferred to the internet network. A loadcell sensor with a capacity of $5000 \mathrm{~g}$ is used to measure the mass of the product in a weigh basket. An on/off button is used to cut and forward the signal, and a $1000 \mathrm{ohm}$ rotating potentiometer is used as the input feature for mass data and the initial moisture content of the dried product. All data is displayed on a $20 \times 4$ LCD screen. Measurement data is sent to the cloud via an internet access point network. 


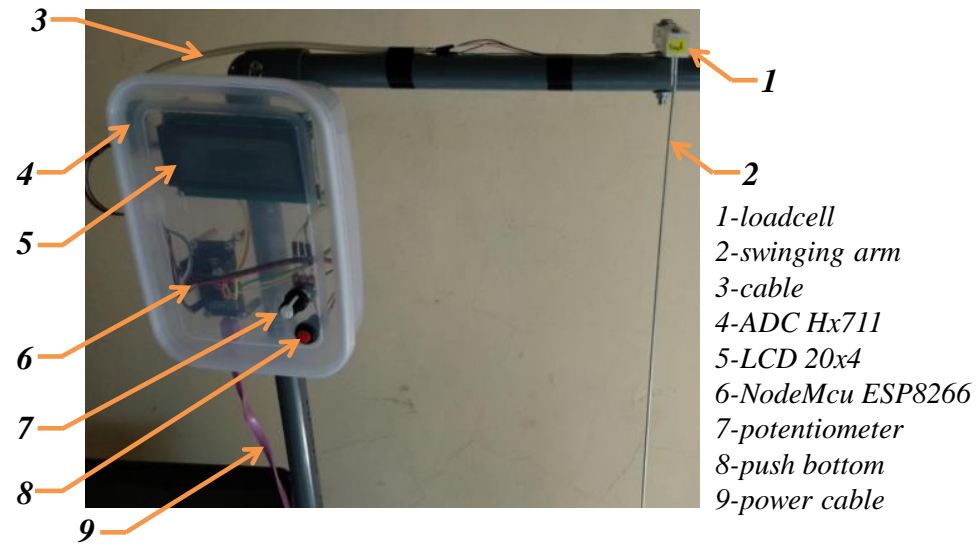

Figure 6. Electronic components of the system

\subsubsection{Algorithm of the program}

The algorithm for the microcontroller for the water content measurement system was developed using the Arduino open-source software. Information system for recording data on Web-logging using the open-source software Notepad ++. Graphical user interface (GUI) for displaying measurement data recording is presented in Figure 7. One example of a data recording page is shown in Figure 8.

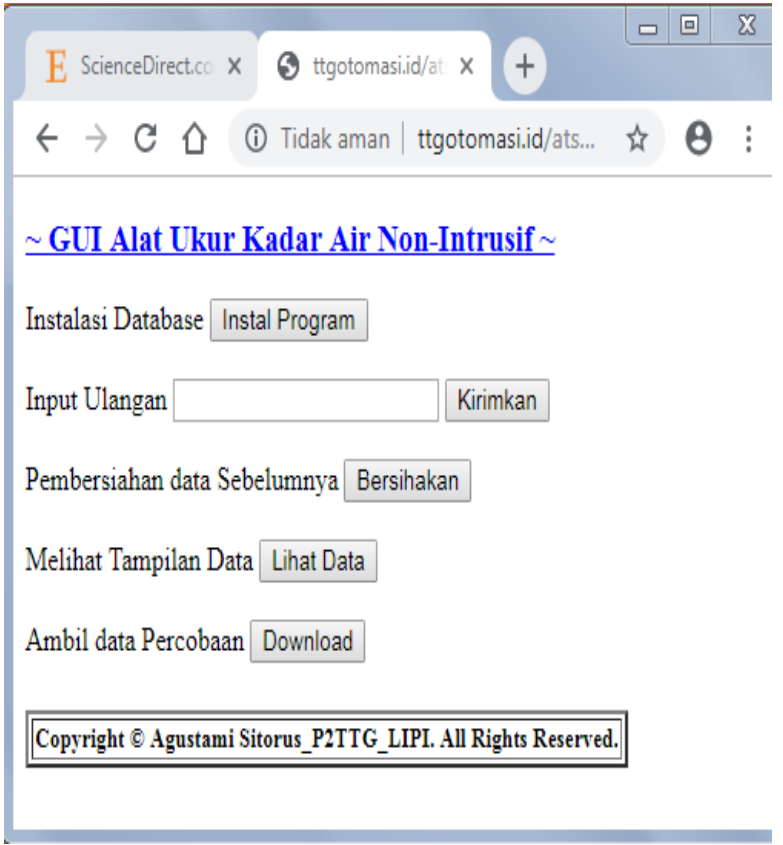

Figure 7. Graphical user interface systemfor measuring non-intrusive water content

\begin{tabular}{|c|c|c|c|c|c|c|c|}
\hline \multicolumn{3}{|c|}{ @ localhost//SFD/GUL.php } & \multicolumn{5}{|c|}{$\times$ localhost/SFD/view1.php $\times+$} \\
\hline \multicolumn{2}{|c|}{$\leftarrow \rightarrow$ C $\Delta$} & \multicolumn{2}{|c|}{ (1) localhost/SFD/view1.ph } & ip मे & (c) & ㅍ. $\mathbb{V} \otimes$ & sc \\
\hline $\begin{array}{l}\text { Data } \\
\text { ke- }\end{array}$ & Tanggal & Waktu & Percobaan & $\begin{array}{l}\text { Initial } \\
\text { Massa } \\
\text { Bahan (s) }\end{array}$ & $\begin{array}{l}\text { Initial } \\
\text { Wc } \\
\text { (\%,bb) }\end{array}$ & $\begin{array}{l}\text { Massa } \\
\text { bahan di } \\
\text { Dryer (gr) }\end{array}$ & $\begin{array}{l}\text { Prediksi } \\
\text { Wc } \\
(\%, b b)\end{array}$ \\
\hline 2996 & $\begin{array}{l}2019- \\
05-29\end{array}$ & $23: 08: 46$ & & 170 & 0.00 & 0.26 & 0.00 \\
\hline 2995 & $\begin{array}{l}2019- \\
05-29\end{array}$ & 23:08:44 & & 172 & 0.00 & 0.02 & 0.00 \\
\hline 2994 & $\begin{array}{l}2019- \\
05-29\end{array}$ & $23: 08: 43$ & & 170 & 0.00 & 0.06 & 0.00 \\
\hline 2993 & $\begin{array}{l}2019- \\
05-29\end{array}$ & $23: 08: 42$ & & 172 & 0.00 & 0.18 & 0.00 \\
\hline 2992 & $\begin{array}{l}2019- \\
05-29\end{array}$ & $23: 08: 41$ & & 172 & 0.00 & 0.00 & 0.00 \\
\hline 2991 & $\begin{array}{l}2019- \\
05-29\end{array}$ & $23: 08: 40$ & & 170 & 0.00 & 0.02 & 0.00 \\
\hline 2990 & $\begin{array}{l}2019- \\
05-29\end{array}$ & 23:08:38 & & 172 & 0.00 & 0.13 & 0.00 \\
\hline 2989 & $\begin{array}{l}2019- \\
05-29\end{array}$ & 23:08:37 & & 170 & 0.00 & 0.02 & 0.00 \\
\hline 2988 & $\begin{array}{l}2019- \\
05-29\end{array}$ & $23: 08: 36$ & & 172 & 0.00 & 0.31 & 0.00 \\
\hline 2987 & $\begin{array}{l}2019- \\
05-29\end{array}$ & 23:08:35 & & 170 & 0.00 & 0.21 & 0.00 \\
\hline
\end{tabular}

Figure 8. Example data recording page

\subsection{Management of load cell signal output}

\subsubsection{Calibration system for moisture measurement}

The calibration system measuring water content aims to show the reliability of the sensors used. Loadcell sensor signal output in the form of analogue data represented by changes in voltage on the loadcell beam when subjected to a load whose unit is $\mathrm{mV}$ as shown in Figure 9. The sensor signal output received by the microcontroller will be forwarded to the personal computer via the internet network. The program algorithm embedded in the microcontroller requires the sensor to send data every second. 
The relationship of the mass of the standard sample $(\mathrm{g})$ with the loadcell sensor signal output $(\mathrm{mV})$ is presented in (6). The equation gives a coefficient of determination $\left(\mathrm{R}^{2}\right)$ close to one. This shows the close relationship between the two parameters. Therefore, this sensor is still acceptable to explain and estimate the weight of the material in the weighing basket. It is in line with the results of the study of Carmona et al. [25], who obtained the results of the calibration of the load cell sensor with a maximum load measurement range of $500 \mathrm{~kg}$. This calibration als o uses root mean square error (RMSE) to determine errors from the sensorestimation.

$$
y=1.0011 x+0.8288 R^{2}=1
$$

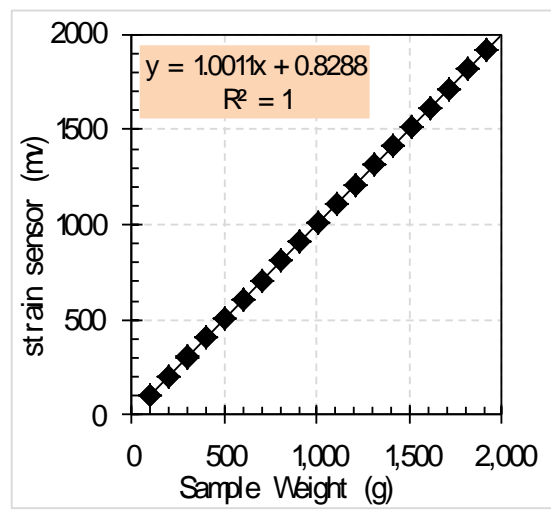

Figure 9. The results of the calibration of the load cell sens or

\subsubsection{Measurement fluctuations against amplitude}

The results of applying amplitude to see the effect of shocks on this water content measurement system are presented in Figure 10. The magnitude applied from the smallest to the largest produces fluctuations in the mass measurement results of the sample, and the measurement time is stable, which varies in each mass of material being tested. The most significant fluctuation of measurement results is found in samples with a mass of $1000 \mathrm{~g}$ and an amplitude of $80 \mathrm{~mm}$, which is $12.39 \%$. The longest stable measurement time due to the application of magnitude in this water content measurement system is found in the $2000 \mathrm{~g}$ sample, which is 3600 seconds, and the shortest is in the sample with a mass of $100 \mathrm{~g}$, which is 26 seconds.

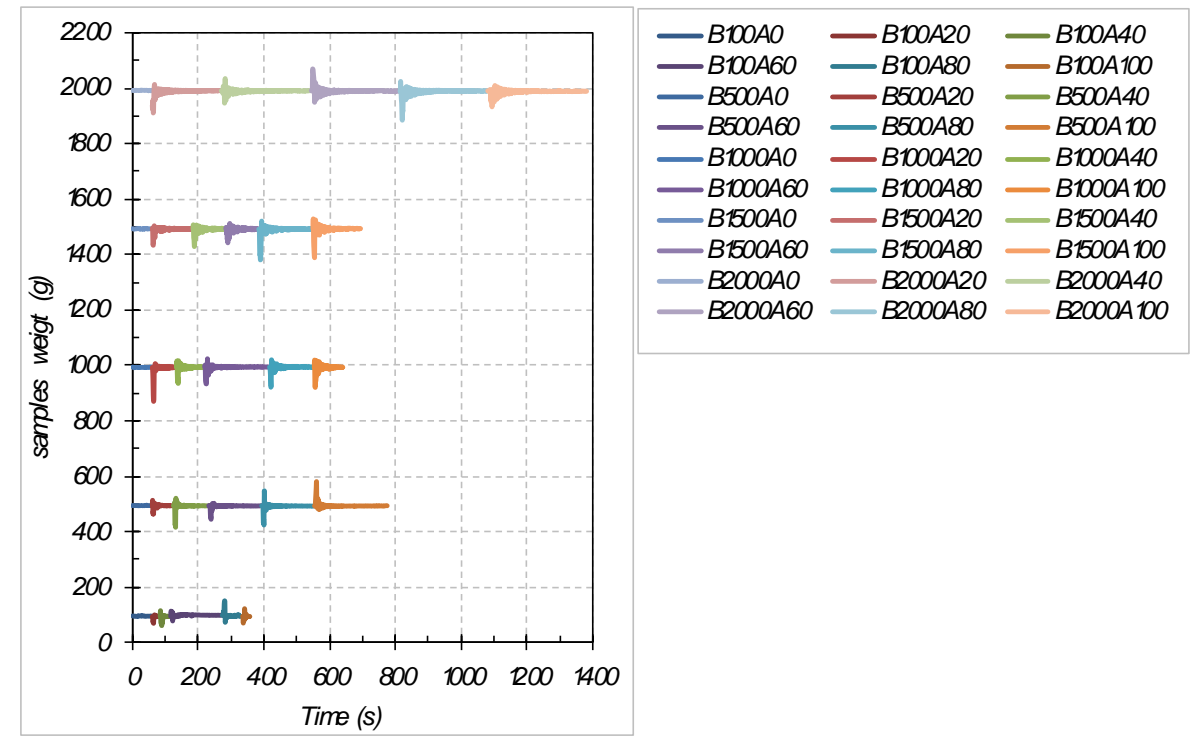

Figure 10. The effect of applying amplitude on the system of measuring water content 
Errors due to fluctuations in the product mass measurement results at each amplitude are presented in Figure 11. The results show that the most significant errors were found in the sample mass of $100 \mathrm{~g}$ and the amplitude of $40 \mathrm{~mm}$. Overall, the test with a sample mass of $100 \mathrm{~g}$ produced the most significant measurement error compared to the mass of the other samples. It is allegedly due to the light condition of the sample mass, which causes the weigh basket and sample to move more freely with a shorter period than when given a heavier load. This is in line with the results of research Susilo et al. [26], who reported that the mass of a harmonic motion mechanism would affect the period of vibration other than the damping constant of the device itself. The most significant standard deviation of the measurement results is the mass treatment of $1000 \mathrm{~g}$ samples with an amplitude of $20 \mathrm{~mm}$ as shown in Figure 12. The smallest standard deviation was found in each treatment, the lowest amplitude of all types of sample masses. The overall standard deviation that occurs from this measurement is less than $3.0 \%$.

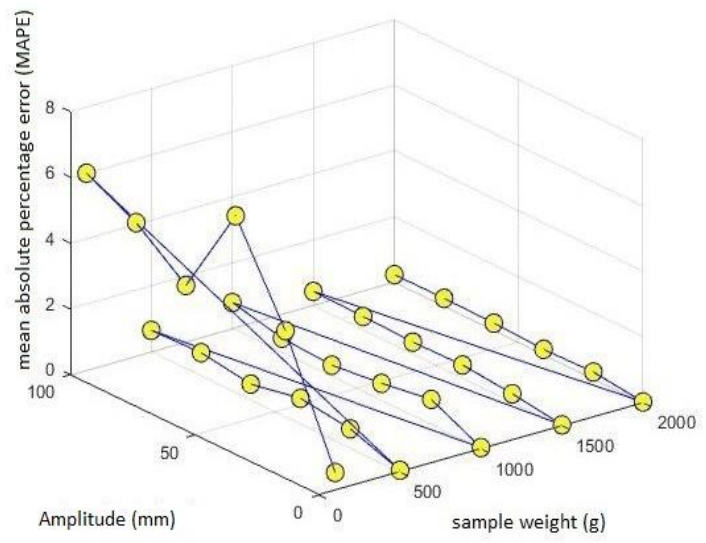

Figure 11. Relationship to treatment of measurement errors

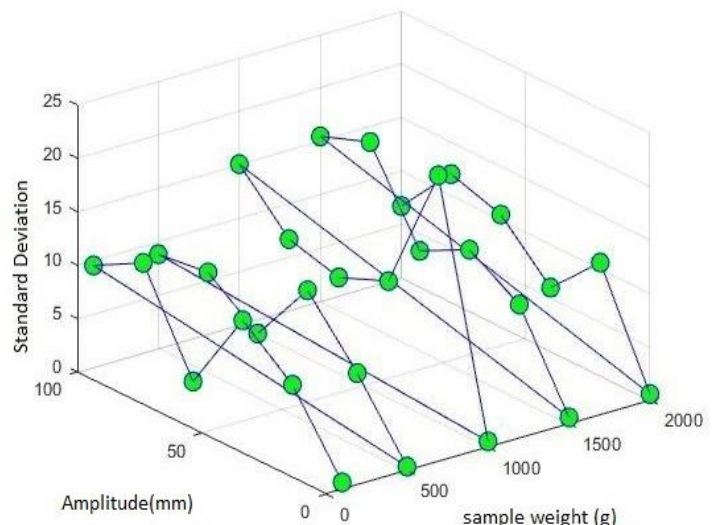

Figure 12. Relationship of treatment to standard deviation of measurement

The longest stable time from measurements measured in the mass treatment of $2000 \mathrm{~g}$ samples and the amplitude of $100 \mathrm{~mm}$ is 360 seconds as shown in Figure 13. The shortest stable measurement time was found in the mass treatment of $100 \mathrm{~g}$ samples, and the amplitude of $100 \mathrm{~mm}$ was 26 seconds. These results indicate that the stable time of measurement tends to be longer under conditions of heavier sample masses compared to lighter ones. Therefore, the results of this study suggest that for some samples equal to or smaller than $2000 \mathrm{~g}$, at least a steady measurement of 151 seconds is required.

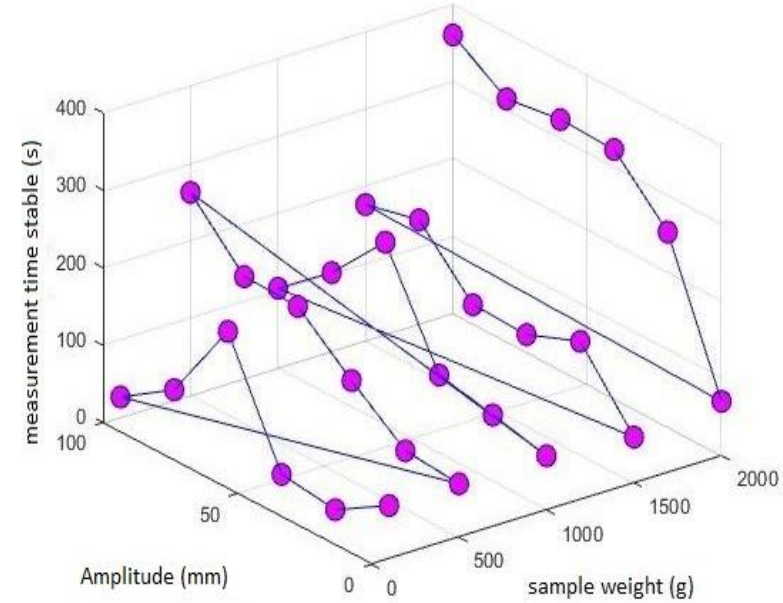

Figure 13. Relationship of treatment to the measurement time stable 


\section{CONCLUSION}

A non-intrusive water level measuring system prepared for fluidizing type dryers has been developed and tested. This system utilizes a load cell sensor and data recording integrated with the internet network. Calibration of the system also shows a very satisfying thing with a coefficient of determination close to one. The error for each measurement is also within the acceptable limit of $6.89 \%$. This paper recommends the use of a measure waiting time of \pm 2.5 minutes for the mass of material dried $2000 \mathrm{~g}$ with a fluidizing type dryer. The next activity of this research is to test the performance of a measurement system integrated with a fluidizing dryer to determine the overall performance of this system.

\section{ACKNOWLEDGEMENTS}

The authors express their appreciation to journal reviewers for their kind and professional advice while considering this manuscript for publication.

\section{REFERENCES}

[1] H. F. M. Yahya, Syafrul Hadi, Edison, "Performance analyses on fluidized bed dryer integrated biomass furnace with and without air preheater for paddy drying," International Journal of Power Electronics and Drive System, vol. 10, no. 3, pp. 1555-1563, 2019.

[2] M. Yahya, A. Fudholi, H. Hafizh, K. Sopian, "Comparison of solar dryer and solar-assisted heat pump dryer for cassava," Solar Energy, vol. 136, pp.606-613, 2016.

[3] A. Fudholi, A. Ridwan, R. Yendra, A. P. Desvina, H. Hartono, M. K. B. Majahar, T. Suyono, K. Sopian. Solar, "Drying Technology in Indonesia: an Overview," International Journal of Power Electronics and Drive Systems., vol. 9, no. 4, pp. 1804-1813, 2018.

[4] S. Sy ahrul, M. Mirmanto, Y. Hartawan, S. Sukmawaty, "Effect of air intake temperature on dry ing time of unhulled rice using a fluidized bed dryer," Heat and Mass Transfer, vol. 55, no. 2, pp. 293-298, 2019.

[5] D. Nowak, B. Gal, A. Włodarska, K. Granat, "The Influence of Microwave Drying Parameters on the Properties of Synthetic Moulding Sands," Archives of Foundry Engineering, vol. 4, pp. 51-54, 2019.

[6] S. Chokphoemphun, S. Chokphoemphun, "Moisture content prediction of paddy drying in a fluidized-bed drier with a vortex flow generator using an artificial neural network," Applied Thermal Engineering, vol. 145, pp. 630-636, 2018.

[7] S. Firouzi, M. R. Alizadeh, D. Haghtalab, "Energy consumption and rice milling quality upon drying paddy with a newly-designed horizontal rotary dry er," Energy, vol. 119, pp. 629-636, 2017.

[8] X.-j. Li, X. Wang, Y. Li, P. Jiang, H. Lu, "Changes in moisture effective diffusivity and glass transition temperature of paddy during dry ing," Computers and Electronics in Agriculture, vol. 128, pp. 112-119, 2016.

[9] G. N. Vieira, M. Olazar, J. T. Freire, F. B. Freire, "Real-time monitoring of milk powder moisture content during drying in a spouted bed dryer using a hybrid neural soft sensor," Drying Technology, vol. 37, no. 9, pp. 1184-1190, 2017.

[10] L. Bennamoun, A. Belhamri, "Design and simulation of a solar dryer for agriculture products," Journal of Food Engineering, vol. 59, no. 2, pp. 259-266, 2003.

[11] M. Simo-Tagne, M. C. Ndukwu, A. Zoulalian, L. Bennamoun, F. Kifani-Sahban, Y. Rogaume, "Numerical analy sis and validation of a natural convection mix-mode solar dryer for drying red chilli under variable conditions," In Press Renewable Energy, vol.151, pp.659-673, 2019.

[12] A. Zoukit, H. El Ferouali, I. Salhi, S. Doubabi, N. Abdenouri, "Simulation, design and experimental performance evaluation of an innovative hybrid solar-gas dryer," Energy, vol. 189, pp.1-15, 2019.

[13] S. M. Jalil, F. Abdurrahman, S. Meliala, R. Rosdiana, "Design of Maximum Power Point Tracking for Solar Collector Drying System: An Experimental Study," Int J Pow Elec \& Dri Syst, vol. 9, no. 4, pp. 1799-1803, 2018

[14] H. Atalay, "Comparative assessment of solar and heat pump dryers with regards to exergy and exergoeconomic performance," Energy, vol. 189, pp. 1-13, 2019.

[15] S. Mehran, M. Nikian, M. Ghazi, H. Zareiforoush, I. Bagheri, "Experimental investigation and energy analy sis of a solar-assisted fluidized-bed dryer including solar water heater and solar-powered infrared lamp for paddy grains dry ing," Solar Energy, vol. 190, pp. 167-184, 2019.

[16] B. Ameri, S. Hanini, M. Boumahdi, "Influence of drying methods on the thermodynamic parameters, effective moisture diffusion and dry ing rate of wastewater sewage sludge," Renewable Energy, vol. 147, 1107-1119, 2017.

[17] A. B. Lingayat, V. Chandramohan, V. Raju, V. Meda, "A review on indirect type solar dryers for agricultural crops-Dryer setup, its performance, energy storage and important highlights," Applied Energy, vol. 258, pp. 1-22, 2020.

[18] O. Lasisi, O. Fapetu, A. Akinola, "Development of a Solar Dryer Incorporated with a Thermal Storage Mechanism," International Journal of Advances in Scientific Research and Engineering. Vol. 6, no, 1, pp. 134-146, 2020.

[19] N. T. A. Othmana, M.E. F. M. Razalib, "Drying of Instant Coffee in a Spray Dryer," Jurnal Kejuruteraan, vol. 31, no. 2, pp. 295-301, 2019.

[20] W. Zhang, X. Cheng, Y. Hu, Y. Yan, "Measurement of moisture content in a fluidized bed dryer using an electrostatic sensor array," Powder Technology, vol. 325, pp. 49-57, 2018. 
[21] W. Zhang, X. Cheng, Y. Hu, Y. Yan, "Online prediction of biomass moisture content in a fluidized bed dryer using electrostatic sensor arrays and the Random Forest method," Fuel, vol. 239, pp. 437-445, 2019.

[22] D. Yogendrasasidhar, Y. P. Setty, "Experimental studies and thin layer modeling of pearl millet using continuous multistage fluidized bed dryer staged externally," Engineering Science and Technology, an International Journal, vol. 22 , no. 2 , pp. 428-438, 2019.

[23] V. Chuwattanakul, S. Eiamsa-ard, "Hydrodynamics investigation of pepper drying in a swirling fluidized bed dryer with multiple-group twisted tape swirl generators," Case Studies in Thermal Engineering, vol. 13, pp. 100366-100375, 2019.

[24] Q. Chen, J. Hu, H. Yang, D. Wang, H. Liu, X. Wang, H. Chen, "Experiment and simulation of the pneumatic classification and drying of coking coal in a fluidized bed dryer," Chemical Engineering Science, vol. 214, pp. 1-14, 2019.

[25] A. M. Carmona, A. I. Chaparro, S. Pardo, R. Velásquez, J. Botero-Valencia, L. Castano-Londono, D. MarquezViloria, C. Botero, A. M. Mesa, "A Low-Cost Sy stem for Monitoring Tower Crane Productivity Cycles Combining Inertial Measurement Units, Load Cells and Lora Networks," Advances in Informatics and Computing in Civil and Construction Engineering, pp.677-684, 2019.

[26] A. Susilo, M. Yunianto, V. I., "Variani. Simulasi gerak harmonik sederhana dan osilasi teredam pada Cassy-E 524000," Indonesian Journal of Applied Physics, vol. 2, no. 2, pp. 1-14, 2012. 